\title{
Analisis Faktor Risiko Sindrom Syok Dengue pada Anak di Rumah Sakit Ibu Anak Bunda Aliyah Jakarta
}

Johanus Edwin, Michelle Olivia Budiarta, Klemens Edward

Departemen Kesehatan Anak RSIA Bunda Aliyah, Jakarta Timur

Latar belakang. Demam berdarah dengue (DBD) merupakan salah satu masalah kesehatan di Indonesia dengan presentasi klinis yang dipengaruhi oleh tingkat kebocoran plasma. Presentasi klinis terburuk adalah sindrom syok dengue (SSD).

Tujuan. Mengidentifikasi faktor risiko SSD pada anak.

Metode. Penelitian ini berupa kasus kontrol dengan menggunakan data rekam medik pasien SSD dan DBD berusia 0-17 tahun. Faktor risiko SSD dianalisis dengan uji chi square, Odds ratio, dan regresi logistik.

Hasil. Dari penelitian ini didapatkan sampel 129 subjek, terdiri dari 43 kasus SSD dan 86 kasus DBD. Uji chi square menunjukkan bahwa jenis kelamin laki-laki, muntah, nyeri perut, kadar hematokrit $\geq 46 \%$, dan kadar trombosit $\leq 50.000 / \mathrm{mm}^{3}$ berhubungan dengan kejadian SSD. Dari hasil analisis regresi logistik didapatkan bahwa jenis kelamin laki-laki, muntah, nyeri perut, kadar hematokrit $\geq 46 \%$, dan kadar trombosit $\leq 50.000 / \mathrm{mm}^{3}$ adalah faktor risiko SSD yang bermakna.

Kesimpulan. Jenis kelamin laki-laki, muntah, nyeri perut, kadar hematokrit $\geq 46 \%$, dan kadar trombosit $\leq 50.000 / \mathrm{mm} 3$ adalah faktor risiko SSD yang bermakna. Sari Pediatri 2019;21(2):109-14

Kata kunci: sindrom syok dengue, demam berdarah dengue, faktor risiko, anak

\section{Risk Factor Analysis for Pediatric Dengue Shock Syndrome in Bunda Aliyah Jakarta Maternity Hospital}

Johanus Edwin, Michelle Olivia Budiarta, Klemens Edward

Background. Dengue hemorrhagic fever (DHF) is one of Indonesia's public health problem. It has a spectrum of clinical presentation based on the severity of plasma leakage. The worst clinical presentation is dengue shock syndrome (DSS).

Objective. To identify the risk factors for DSS.

Methods. This case control study used the medical records of DSS and DHF patients aged 0 - 17 years old. The risk factors for DSS were determined by chi square test, odds ratio, and logistic regression analysis.

Result. Of the 129 subjects, 43 were diagnosed with DSS and 86 were diagnosed with DHF. The significant risk factors for DSS were male, vomiting, abdominal pain, hematocrit $\geq 46 \%$, and thrombocyte $\leq 50.000 / \mathrm{mm}^{3}$. Logistic regression analysis showed that male, vomiting, abdominal pain, hematocrit $\geq 46 \%$, and thrombocyte $\leq 50.000 / \mathrm{mm} 3$ are significantly associated with DSS.

Conclusion. Male, vomiting, abdominal pain, hematocrit $\geq 46 \%$, and thrombocyte $\leq 50.000 / \mathrm{mm}^{3}$ are significant risk factors of

DSS. Sari Pediatri 2019;21(2):109-14

Keywords: dengue shock syndrome, dengue hemorrhagic fever, risk factors, children

Alamat korespondensi: Johanus Edwin. Departemen Kesehatan Anak RSIA Bunda Aliyah, Jakarta Timur. Email: pjedwin1@gmail.com 


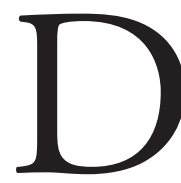
emam berdarah dengue (DBD) merupakan penyakit yang disebabkan oleh virus dan ditularkan melalui arthropoda. Virus dengue memiliki 4 macam serotipe, yaitu DENV 1 - 4 yang ditularkan oleh nyamuk Aedes. ${ }^{1}$ Secara global diperkirakan sekitar 50 hingga 100 juta kasus infeksi virus dengue terjadi setiap tahunnya yang tersebar hingga hampir setengah populasi dunia, terutama di daerah yang terdapat lebih dari 1 tipe virus, contohnya seperti di Asia Tenggara dan Asia Pasifik yang dikenal sebagai area hiperendemik. ${ }^{2}$ Pada tahun 2017, terdapat 68.407 kasus DBD yang dilaporkan di Indonesia dengan kasus yang meninggal sebanyak 493 orang. ${ }^{3}$

Spektrum klinis infeksi DBD dipengaruhi oleh tingkat kebocoran plasma dan manifestasi perdarahan. Sindrom syok dengue (SSD) merupakan bentuk yang paling parah dan biasanya terjadi pada kelompok anak atau remaja muda. ${ }^{4}$ Tingkat keparahan SSD sendiri bervariasi dari syok ringan yang responsif terhadap resusitasi cairan kristaloid parenteral hingga yang berat dan resusitasi yang lebih agresif, termasuk obat inotropik dan perawatan intensif. 5 Tingkat kematian dari SSD dilaporkan 50 kali lebih tinggi dibandingkan dengan pasien DBD tanpa syok. Diperkirakan sebanyak $50 \%$ pasien DBD yang tidak ditangani dengan benar mengalami kematian. Penelitian lain menyatakan sebanyak $20-23 \%$ pasien DBD mengalami syok. ${ }^{6}$ Berdasarkan fakta ini, penting bagi tenaga kesehatan untuk mendeteksi dan menangani pasien anak dengan risiko tinggi SSD dengan lebih cermat untuk mencegah kematian. ${ }^{7}$ Penelitian terdahulu membahas mengenai serotipe virus dengue dan infeksi sekunder sebagai faktor risiko SSD. Namun penelitian mengenai faktor risiko SSD berupa manifestasi klinis, seperti jenis kelamin, usia, status gizi, nyeri perut, dan muntah masih beragam hasilnya. Oleh karena itu, kami melakukan penelitian untuk mengidentifikasi jenis kelamin, usia, status gizi, nyeri perut, muntah, kadar hematokrit dan kadar trombosit sebagai faktor risiko SSD.

\section{Metode}

Penelitian ini menggunakan metode penelitian kasus kontrol dengan sampel pasien anak usia $0-17$ tahun dengan diagnosis DBD dan SSD di IGD RSIA Bunda Aliyah Jakarta dan atau dirawat di RSIA Bunda Aliyah
Jakarta dari Januari 2016 - Juli 2019. Data yang digunakan merupakan data sekunder dari rekam medik pasien. Pengambilan sampel pasien SSD dilakukan dengan metode purposive sampling dan pasien DBD dilakukan dengan metode simple random sampling dengan perbandingan sampel 1:2. Hal ini dikarenakan jumlah pasien DBD yang mengalami syok lebih sedikit dibandingkan dengan pasien yang tidak mengalami syok.

Kriteria inklusi adalah pasien anak usia $0-17$ tahun dengan diagnosis DBD dan SSD menurut kriteria WHO (World Health Organization) 2011. Kriteria eksklusi berupa pasien dengan riwayat penyakit hematologi, seperti hemofilia, dan diagnosis sekunder berupa infeksi lainnya. Subjek penelitian dibagi menjadi dua kelompok, yaitu kelompok kasus (SSD) dan kelompok kontrol (DBD).

Faktor risiko yang dianalisis berupa faktor individu dan pemeriksaan laboratorium. Faktor individu berupa jenis kelamin, usia, dan status gizi (berat badan menurut umur), riwayat muntah dan nyeri perut. Data pemeriksaan laboratorium berupa kadar hematokrit dan trombosit.

Analisis statistik dilakukan menggunakan program statistik SPSS versi 24.0. Faktor risiko terkait SSD berupa jenis kelamin, usia, status gizi, muntah, nyeri perut, kadar hematokrit, dan kadar trombosit dianalisis dengan uji chi square dan Odds ratio (OR) dengan interval kepercayaan (IK) 95\% dengan $\mathrm{p}<0,05$ adalah bermakna. Pada faktor risiko yang memiliki hasil bermakna kemudian dilakukan analisis regresi logistik untuk menilai besarnya pengaruh dari masing-masing faktor risiko dengan IK 95\% dengan $\mathrm{p}<0,05$ adalah bermakna.

Studi ini telah disetujui oleh Komite Etik RSIA Bunda Aliyah Jakarta.

\section{Hasil}

Pada penelitian ini didapatkan 129 sampel yang memenuhi kriteria sampel dengan distribusi sebanyak 43 sampel pasien SSD dan 86 DBD. Distribusi sebaran data sampel normal. Data karakteristik subjek penelitian tertera pada Tabel 1 .

Usia subjek penelitian yang paling muda adalah 6 bulan dan usia tertua adalah 16 tahun. Pada kelompok SSD didapatkan rerata usia 8,6 tahun, sedangkan pada kelompok DBD didapatkan rerata usia 6,7 
Tabel 1. Karakteristik subjek $(\mathrm{n}=43)$

\begin{tabular}{|c|c|c|c|c|c|}
\hline & & \multicolumn{2}{|l|}{ SSD } & \multicolumn{2}{|c|}{ DBD } \\
\hline & & $\%$ & n (86) & $\%$ & \\
\hline \multirow[t]{2}{*}{ Jenis kelamin } & Laki-laki & 29 & 67,4 & 39 & 45,3 \\
\hline & Perempuan & 14 & 32,6 & 47 & 54,7 \\
\hline \multirow[t]{3}{*}{ Usia (tahun) } & Rerata & 8,6 & & 6,7 & \\
\hline & Median & 8 & & 6 & \\
\hline & SD & 3,6 & & 3,8 & \\
\hline \multirow[t]{3}{*}{ Status gizi } & Berlebih & 12 & 27,9 & 24 & 27,9 \\
\hline & Baik & 21 & 48,8 & 53 & 61,6 \\
\hline & Kurang & 10 & 23,3 & 9 & 10,5 \\
\hline \multirow[t]{2}{*}{ Muntah } & $\mathrm{Ya}$ & 38 & 88,4 & 28 & 32,6 \\
\hline & Tidak & 5 & 11,6 & 58 & 67,4 \\
\hline \multirow[t]{2}{*}{ Nyeri perut } & Ya & 33 & 76,7 & 14 & 16,3 \\
\hline & Tidak & 10 & 23,3 & 72 & 83,7 \\
\hline \multirow[t]{3}{*}{ Hematokrit (\%) } & Rerata & 45,2 & & 36,9 & \\
\hline & SD & 5,5 & & 3,9 & \\
\hline & Range & $33-58$ & & $28-46$ & \\
\hline \multirow[t]{3}{*}{ Trombosit $\left(/ \mathrm{mm}^{3}\right)$} & Rerata & $43.627,9$ & & $83.569,7$ & \\
\hline & SD & $21.026,1$ & & $14.112,6$ & \\
\hline & Range & $14.000-89.000$ & & $39.000-60.000$ & \\
\hline
\end{tabular}

Tabel 2. Analisis chi-square faktor risiko terkait SSD

\begin{tabular}{|c|c|c|c|c|c|c|c|}
\hline & & & & & & & \\
\hline & $\mathrm{n}(43)$ & $\%$ & $\mathrm{n}(86)$ & $\%$ & OR & $1 \mathrm{~K}$ & $\mathrm{p}$ \\
\hline Jenis kelamin & & & & & & & \\
\hline Laki-laki & 29 & 67,4 & 39 & 45,3 & 2,7 & $1,27-5,91$ & 0,009 \\
\hline Usia & & & & & & & \\
\hline$<9$ tahun & 22 & 51,2 & 59 & 68,6 & 0,47 & $0,22-1,01$ & 0,053 \\
\hline Status gizi & & & & & & & \\
\hline Berat badan berlebih & 12 & 27,9 & 24 & 27,9 & 1,17 & $0,65-2,12$ & 0,595 \\
\hline Berat badan baik & 21 & 48,8 & 53 & 61,6 & & & Reff \\
\hline Berat badan kurang & 9 & 20,9 & 9 & 10,5 & 0,39 & $0,14-1,13$ & 0,079 \\
\hline Muntah & 38 & 88,4 & 28 & 32,6 & 15,7 & $5,58-44,35$ & $0,000^{*}$ \\
\hline Nyeri perut & 33 & 76,7 & 14 & 16,3 & 16,9 & $6,83-42,16$ & $0,000^{*}$ \\
\hline Pemeriksaan laboratorium & & & & & & & \\
\hline Hematokrit $46 \%$ & 22 & 51,2 & 2 & 2,3 & 44,0 & $9,58-20,20$ & $0,000^{*}$ \\
\hline Trombosit $50.000 / \mathrm{mm}^{3}$ & 26 & 60,5 & 1 & 1,2 & 13,0 & $1,60-10,24$ & $0,000^{*}$ \\
\hline${ }^{*} \mathrm{p}<0,05$ & & & & & & & \\
\hline Tabel 3. Analisis regresi log & isiko terl & SSD & & & & & \\
\hline & & & SE & $\operatorname{Exp}(B)$ & & IK95\% & $\mathrm{p}$ \\
\hline Jenis kelamin laki-laki & 1,73 & & 0,860 & 5,654 & & $1,04-30,51$ & 0,044 \\
\hline Muntah & 2,30 & & 0,885 & 10,01 & & $1,50-56,05$ & 0,009 \\
\hline Nyeri perut & 2,04 & & 0,788 & 7,70 & & $1,64-36,10$ & 0,010 \\
\hline Hematokrit 46\% & 3,36 & & 1,255 & 23,484 & & $5,37-6,26$ & 0,007 \\
\hline Trombosit $50.000 / \mathrm{mm}^{3}$ & 4,59 & & 1,324 & 19,896 & & $7,38-13,26$ & 0,001 \\
\hline
\end{tabular}


tahun. Pada kelompok SSD paling banyak didapatkan pasien laki-laki $(67,4 \%)$ dan pada kelompok DBD didapatkan distribusi jenis kelamin yang sama. Status gizi pada mayoritas pasien dengan diagnosis SSD dan DBD tergolong baik. Pada kelompok pasien SSD, mayoritas mengalami muntah dan nyeri perut. Pasien SSD mengalami hemokonsentrasi dengan rentang kadar hematokrit 33\%-58\% dengan kadar trombosit $14.000-89.000 / \mathrm{mm}^{3}$, sedangkan pada kelompok DBD memiliki rentang kadar hematokrit 28\%-46\% dengan kadar trombosit 39.000-60.000/ $\mathrm{mm}^{3}$.

Berdasarkan hasil analisis chi square, didapatkan bahwa jenis kelamin laki-laki (OR=2,7, IK95\% $1,27 ; 5,91)$, muntah $(\mathrm{OR}=15,7$, IK95\% 5,58;44,35), nyeri perut $(\mathrm{OR}=16,9$, IK95\% 6,83;42,16), kadar hematokrit 6\% $(\mathrm{OR}=22,5$, IK95\% 7,28;69,45), dan kadar trombosit $\leq 50.000 / \mathrm{mm}^{3}(\mathrm{OR}=13,0, \mathrm{IK} 95 \%$ $1,60 ; 10,24)$ berhubungan dengan kejadian SSD secara bermakna.

Faktor-faktor ini kemudian dianalisa dengan uji regresi logistik dan didapatkan bahwa jenis kelamin laki-laki $(\mathrm{OR}=5,654$, IK95\% 1,04;30,51), muntah $(\mathrm{OR}=10,01$, IK95\% 1,50;56,05), nyeri perut $(\mathrm{OR}=$ 7,70, IK95\% 1,64;36,10), kadar hematokrit 6\% $(\mathrm{OR}=23,484$, IK95\% 5,37;6,26), dan kadar trombosit $\leq 50.000 / \mathrm{mm}^{3}(\mathrm{OR}=19,896$, IK95\% 7,38-13,26) adalah faktor risiko SSD yang bermakna. Data analisis chi square tertera pada Tabel 2 dan analisis regresi logistik tertera pada Tabel 3.

Dalam penelitian ini, faktor risiko usia dan status gizi tidak memiliki hubungan dengan kejadian SSD.

\section{Pembahasan}

Dalam penelitian ini, didapatkan bahwa jenis kelamin pria memiliki risiko mengalami SSD sebanyak lima kali. Hubungan antara jenis kelamin dengan SSD pada penelitian-penelitian sebelumnya beragam. Dalam penelitian Salsabila $\mathrm{dkk}^{8}$ dan Raihan dkk, anak laki-laki memiliki risiko mengalami SSD dibandingkan anak perempuan, ${ }^{9}$ sebaliknya pada penelitian Lam dkk, anak perempuan memiliki risiko mengalami SSD yang lebih tinggi. ${ }^{5}$ Berbeda dengan penelitian lainnya, menurut Junia $^{6}$ dan Tantracheewathorn ${ }^{10}$ tidak didapatkan adanya hubungan yang bermakna antara SSD dan jenis kelamin. Penelitian oleh Salsabila dkk dilakukan di negara yang sama dengan penelitian ini sehingga memiliki hasil yang sama, sedangkan penelitian lainnya dilakukan di Vietnam dan Thailand. Pada penelitian ini didapat anak laki-laki lebih banyak dibandingkan anak perempuan sesuai dengan penelitian dari Soedarmo dkk dikarenakan pembentukan immunoglobulin dan antibodi pada laki-laki kurang efektif. Hal ini dapat mengakibatkan anak laki-laki memiliki risiko infeksi lebih tinggi atau mengalami derajat keparahan yang lebih buruk dibandingkan anak perempuan. ${ }^{11}$

Pada penelitian ini, kami membagi kelompok usia anak menjadi di bawah sembilan tahun dan usia 9-17 tahun karena angka kejadian SSD dan DBD pada penelitian ini banyak ditemukan pada anak usia kurang dari sembilan tahun. Hasil analisis chi square didapatkan bahwa usia tidak memiliki hubungan yang bermakna dengan kejadian SSD. Berdasarkan penelitan-penelitian lainnya, anak-anak usia di bawah sembilan tahun cenderung mengalami syok. Semakin muda usia pasien, akan semakin tinggi risiko mengalami kematian. ${ }^{4-6,9}$ Di negara-negara Asia angka kejadian syok lebih banyak didapatkan pada populasi anak, sedangkan di Amerika lebih banyak didapatkan pada orang dewasa. ${ }^{12}$ Risiko terjadinya SSD pada anak meningkat pada usia 4-12 tahun, kemudian risiko terjadinya syok akan menurun hingga usia remaja. ${ }^{9}$ Indonesia merupakan negara endemik infeksi dengue sehingga banyak kejadian syok pada anak dengan infeksi sekunder. ${ }^{1}$

Pada penelitian ini tidak didapatkan adanya hubungan yang bermakna antara status gizi dengan SSD. Hal yang sama ditemukan pada penelitian Lovera $\mathrm{dkk}^{4}$ yang dilakukan di Paraguay, akan tetapi beberapa penelitian lain seperti yang dilakukan oleh Junia dkk, menunjukkan bahwa anak dengan status gizi berlebih memiliki risiko 1,98 kali lebih tinggi untuk terjadi SSD. ${ }^{9}$ Penelitian lainnya oleh Raihan dkk, ${ }^{9}$ juga menunjukkan bahwa anak dengan status gizi kurang sangat jarang terkena SSD dibandingkan anak dengan status gizi baik. Hal ini berdasarkan teori bahwa pada anak dengan status gizi yang baik, aktivitas sistem imun akan berkembang dengan baik dan akan menyebabkan proliferasi virus meningkat. Berkebalikan dengan apa yang terjadi pada anak dengan status gizi kurang atau buruk dimana terjadi inhibisi dari proliferasi virus dikarenakan menurunnya suplai energi yang diperlukan oleh reaksi anabolik. ${ }^{6,13}$

Muntah merupakan salah satu keluhan yang paling banyak didapatkan pada infeksi dengue dan secara signifikan lebih banyak ditemukan pada pasien SSD. Berdasarkan hasil analisa regresi logistik, keluhan 
muntah meningkatkan risiko terjadinya SSD sebanyak 10 kali lipat. Penelitian lain menyatakan bahwa muntah persisten yaitu sebanyak dua kali atau lebih dalam satu hari merupakan faktor prediktor infeksi dengue yang berat. ${ }^{14}$ Namun, pada penelitian Junia ${ }^{6}$ dan Lovera, ${ }^{4}$ muntah tidak memiliki hubungan yang bermakna dengan kejadian SSD.

Pada penelitian kami, terdapat $33(76,6 \%)$ pasien dengan SSD yang mengalami nyeri perut. Angka tersebut sudah dua kali lebih tinggi dibandingkan angka pada pasien dengan DBD yang mengalami nyeri perut yaitu $14(16,3 \%)$ pasien. Hal ini menunjukkan bahwa nyeri perut dapat menjadi prediktor yang baik untuk melihat terjadinya SSD. Penelitian lain yang dilakukan oleh Junia $\mathrm{dkk}^{6}$ dan Satari $\mathrm{dkk}^{13}$ juga mendapatkan hasil yang sama dengan penelitian kami. Penelitian meta analisis yang dilakukan oleh Huy $\mathrm{dkk}^{7}$ juga mengatakan bahwa nyeri perut memiliki hubungan sebagai faktor risiko pada SSD. Nyeri perut merupakan tanda akibat terjadinya perdarahan dari saluran pencernaan dan atau hepatomegali. Ada penelitian lain yang mengatakan bahwa saat fase syok atau presyok, suplai darah ke organ viseral berkurang sehingga menyebabkan hipoksia yang akhirnya akan diikuti oleh nyeri perut. ${ }^{15}$

Badan kesehatan dunia WHO menetapkan peningkatan hematokrit sebanyak 20\% atau lebih sebagai salah satu kriteria diagnosis DBD. ${ }^{16}$ Dari penelitian ini didapatkan bahwa peningkatan kadar hematokrit $\geq 46 \%$ merupakan faktor risiko terjadinya SSD yang bermakna. Penelitian lainnya yang dilakukan di Indonesia oleh Raihan $\mathrm{dkk}^{9}$ mendapatkan kadar hematokrit $\geq 42 \%$ sebagai faktor risiko syok, sedangkan penelitian Dewi $\mathrm{dkk}^{17}$ mendapatkan kadar hematokrit 46\%-50\% sebagai faktor risiko syok. Kadar hematokrit merupakan bukti adanya hemokonsentrasi akibat kebocoran plasma. Namun, peningkatan kadar hematokrit juga dapat diartikan sebagai tandatanda dehidrasi atau perdarahan sehingga dapat menimbulkan bias. ${ }^{16}$

Penelitian oleh Pongpan dkk menunjukkan angka platelet $\leq 100.000 / \mathrm{mm}^{3}$ sebagai faktor risiko terhadap terjadinya SSD. ${ }^{15}$ Beberapa penelitian juga mengatakan bahwa angka platelet $<20.000 / \mathrm{mm}^{3}$ tidak menjadi faktor risiko terhadap terjadinya SSD. ${ }^{4,18}$ Pada penelitian kami, kami mendapatkan bahwa angka platelet $\leq 50.000 / \mathrm{mm}^{3}$ merupakan faktor risiko untuk terjadinya SSD, hasil ini sama dengan penelitian yang dilakukan oleh Pothapregada dkk yang mengatakan bahwa angka platelet $\leq 50.000 / \mathrm{mm}^{3}$ merupakan faktor yang signifikan terhadap terjadinya SSD ${ }^{19} \mathrm{Ada}$ beberapa hipotesa tentang mekanisme virus DENV dapat menyebabkan trombositopenia, yaitu dapat secara langsung atau tidak langsung menghambat kapasitas proliferasi dari sel hematopoietik di sumsum tulang dan memang ada bukti bahwa DENV dapat menyebabkan hipoplasia dari sumsum tulang. ${ }^{20}$

Keterbatasan dari penelitian yang kami lakukan ini adalah data berasal dari rekam medik sehingga sangat bergantung pada kelengkapan data yang tersimpan dalam rekam medik masing-masing pasien dan dapat menimbulkan bias.

\section{Kesimpulan}

Dari penelitian ini dapat disimpulkan bahwa jenis kelamin laki-laki, muntah, nyeri perut, kadar hematokrit $6 \%$, dan kadar trombosit $\leq 50.000 / \mathrm{mm}^{3}$ adalah faktor risiko SSD yang bermakna. Faktor risiko usia dan status gizi tidak memiliki hubungan yang bermakna dengan SSD.

\section{Daftar pustaka}

1. Guzman MG, Harris E. Dengue. The Lancet 2015;385:45365.

2. Cucunawangsih, Lugito NPH. Trends of dengue disease epidemiology. Virol Res Treat 2017;8:1178122X1769583.

3. Indriyani Y, Wahyudi T. Situasi penyakit demam berdarah di Indonesia tahun 2017. Jakarta: Pusat Data dan Informasi Kementerian Kesehatan RI; 2017.

4. Lovera D, Martinez de Cuellar C, Araya S, Amarilla S, Gonzalez N, Aguiar C, dkk. Clinical characteristics and risk factors of dengue shock syndrome in children. Pediatr Infect Dis J 2016;35:1294-9.

5. Lam PK, Hoai Tam DT, Dung NM, Hanh Tien NT, Thanh Kieu NT, Simmons C, dkk. A Prognostic model for development of profound shock among children presenting with dengue shock syndrome. PLOS ONE 2015;10:e0126134.

6. Junia J, Garna H, Setiabudi D. Clinical risk factors for dengue shock syndrome in children. Paediatr Indones 2007;47:7.

7. Huy NT, Van Giang T, Thuy DHD, Kikuchi M, Hien TT, Zamora J, dkk. Factors associated with dengue shock syndrome: a systematic review and meta-analysis. PLoS Negl Trop Dis 2013;7:e2412. 
8. Salsabila O, Shodikin MA, Rachmawati DA. Analisis faktor risiko terjadinya sindrom syok dengue pada anak di RSD dr. Soebandi Kabupaten Jember. J Agromedicine Med Sci 2017;3:56-61.

9. Raihan, Hadinegoro SRS, Tumbelaka AR. Faktor prognosis terjadinya syok pada demam berdarah dengue. Sari Pediatri 2010;12:47-52.

10. Tantracheewathorn T, Tantracheewathorn S. Risk factors of dengue shock syndrome in children. J Med Assoc Thai 90:2727.

11. Soedarmo S, Garna H, Hadinegoro SRS, Satari H. Buku ajar infeksi \& pediatri tropis. 2 ed. Jakarta: Badan Penerbit IDAI; 2010.

12. Martina BEE, Koraka P, Osterhaus ADME. Dengue virus pathogenesis: an integrated view. Clin Microbiol Rev 2009;22:564-81.

13. Satari HI, Mardani RA, Gunardi H. Faktor prognosis sindrom syok dengue pada anak. Sari Pediatri 2018;20:131-7.

14. Vuong NL, Manh DH, Mai NT, Phuc LH, Luong VT, Quan VD, dkk. Criteria of "persistent vomiting" in the WHO 2009 warning signs for dengue case classification. Dikutip 26 Juli 2019 Didapat dari: http://tropmedhealth.biomedcentral.com/ articles/10.1186/s41182-016-0014-9.

15. Pongpan. Prognostic indicators for dengue infection severity. Dikutip 28 Juli 2019. Didapat dari: http://www.theijcp.org/ index.php/ijcp/article/view/73.

16. World Health Organization, penyunting. Comprehensive guidelines for prevention and control of dengue and dengue haemorrhagic fever, Rev, and expanded. ed. New Delhi, India: World Health Organization Regional Office for South-East Asia; 2011.

17. Dewi R, Tumbelaka AR, Sjarif DR. Clinical features of dengue hemorrhagic fever and risk factors of shock event. Paediatr Indones 2016;46:144.

18. Widiyati MMT, Laksanawati IS, Prawirohartono EP. Obesity as a risk factor for dengue shock syndrome in children. Paediatr Indones 2013;53:187.

19. Pothapregada S, Kamalakannan B, Thulasingham M. Risk factors for shock in children with dengue fever. Indian J Crit Care Med 2015;19:661-4.

20. Azeredo EL de, Monteiro RQ, de-Oliveira Pinto LM. Thrombocytopenia in dengue: interrelationship between virus and the imbalance between coagulation and fibrinolysis and inflammatory mediators. Mediators Inflamm 2015;2015:1-16. 